\section{Analysis of oil reserves, production and oil price trends in 1995, 2005, 2015}

The Mining-Geology-Petroleum Engineering Bulletin UDC: $553.9: 620.9$

DOI: $10.17794 / \mathrm{rgn} .2018 .4 \cdot 10$

Review scientific paper

\author{
Marija Ledenko'; Josipa Velić́z; Daria Karasalihović Sedlar² \\ ${ }^{1}$ Selska cesta 46, HR 10000 Zagreb \\ ${ }^{2}$ Pierottijeva 6, HR 10000 Zagreb (University of Zagreb, Faculty of Mining, Geology and Petroleum Engineering)
}

\begin{abstract}
According to analysed oil reserves and oil production worldwide during 1995, 2005 and 2015, a global increase in oil reserves is observed. In 1995, there were $179.1 \times 10^{9} \mathrm{~m}^{3}$, in 2005 there were $218.5 \times 10^{9} \mathrm{~m}^{3}$ and in 2015 there were $269.9 \times 10^{9}$ $\mathrm{m}^{3}$ oil reserves. According to British Petroleum data, oil production is also increasing, but by a smaller ratio. Oil production in the world in 1995 was $10.8 \times 10^{9} \mathrm{~m}^{3}$, in 2005 it was $13.0 \times 10^{9} \mathrm{~m}^{3}$, and in $201514.6 \times 10^{9} \mathrm{~m}^{3}$. Oil price trends between 1980 and 2015 were analysed. Many different causes affect the constant oil price fluctuations, but the most influential are the geopolitical crises of the Middle Eastern countries, as well as a great increase in demand for oil and the expansion of the consumption of wealthy countries such as China, India and Brazil, which was not accompanied by a corresponding increase in supply. Modern political relations are full of conflicts, which greatly affect oil prices, and the best example is the short-term rise in oil prices in 2011, when armed conflicts started in Libya, or disablement of production in countries such as Syria and Yemen, which in 2015 can barely capture any production. By comparing reserves, earnings and oil price fluctuations, it is apparent that almost every increase in oil production, after the discovery of oil deposits, was later accompanied by a fall in prices.
\end{abstract}

Keywords:

oil reserves, oil production, oil prices, oil consumption

\section{Introduction}

Oil and gas reserves are one of the most precious forms of energy that mankind today possesses, and the management of energy mineral resources is one of the most important factors in the development of each country. Oil and natural gas are the main energy mineral resources and make 60 to $80 \%$ of total energy consumption in most countries. Sudden price changes of oil and other petroleum products through history show that oil price fluctuation is unpredictable and constant estimates of reserves are necessary as well as adjusting strategies for oil exploration. Energy consumption in the ' 90 s of the $20^{\text {th }}$ century gradually and moderately increased, and more intense growth was achieved in the early $21^{\text {st }}$ century. With growth in energy consumption, the demand for oil is also growing and oil has become extremely significant for the industry, and its possession is a prerequisite for further development of the economy of an individual country.

Throughout the history of hydrocarbon exploration, geologists encountered the problem of oil reserves limit as well as their exploitation. In 1956, Marion King Hub-

Corresponding author: Marija Ledenko

topic.marija@gmail.com bert announced forecasts for future reserves and oil exploration in the world and calculated that the world's oil production would begin to decline at the beginning of the 21st century (Dekanić, 2011).

According to Hubbert, the curve describing global oil exploration at a time called Hubbert's curve, and maximum exploitation at Hubbert peak or Peak Oil (Hubbert, 1969). Analysed data in this work shows that each of the predictions of Hubbert's followers has proven wrong and that the reserves for the observed years are increasing.

Thus, the total proven oil reserves in the world in 1995 amounted to $179.1 \times 10^{9} \mathrm{~m}^{3}$, in 2005 the reserves amounted to $218.5 \times 10^{9} \mathrm{~m}^{3}$ and in 2015 they were on the level of $269.9 \times 10^{9} \mathrm{~m}^{3}$. Oil production in the years 1995 , 2015 and 2015 amounts to $10.8 \times 10^{9} \mathrm{~m}^{3}, 13 \times 10^{9} \mathrm{~m}^{3}$, and $14.6 \times 10^{9} \mathrm{~m}^{3}$ respectively (BP, 2016). This paper presents data on oil reserves and oil capture in the world according to British Petroleum data for 1995, 2005 and 2015 and the price trends of oil in the last 30 years.

\section{Oil Reserves and Production}

The term "oil reserves" refers to the amount of oil in the reservoir that can be technically and economically 

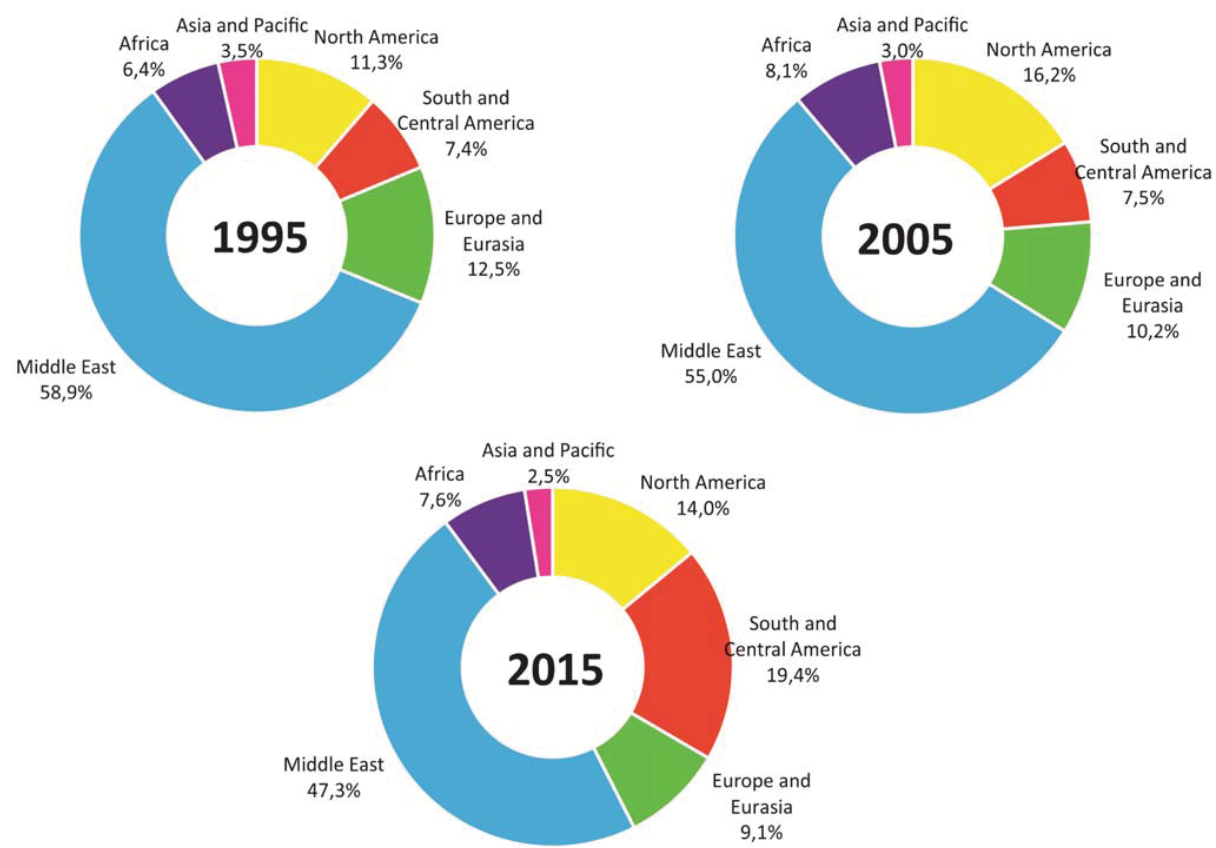

Figure 1: Distribution of Oil Reserves in the world 1995, 2005 and 2015 (adjusted to: BP, 2016)
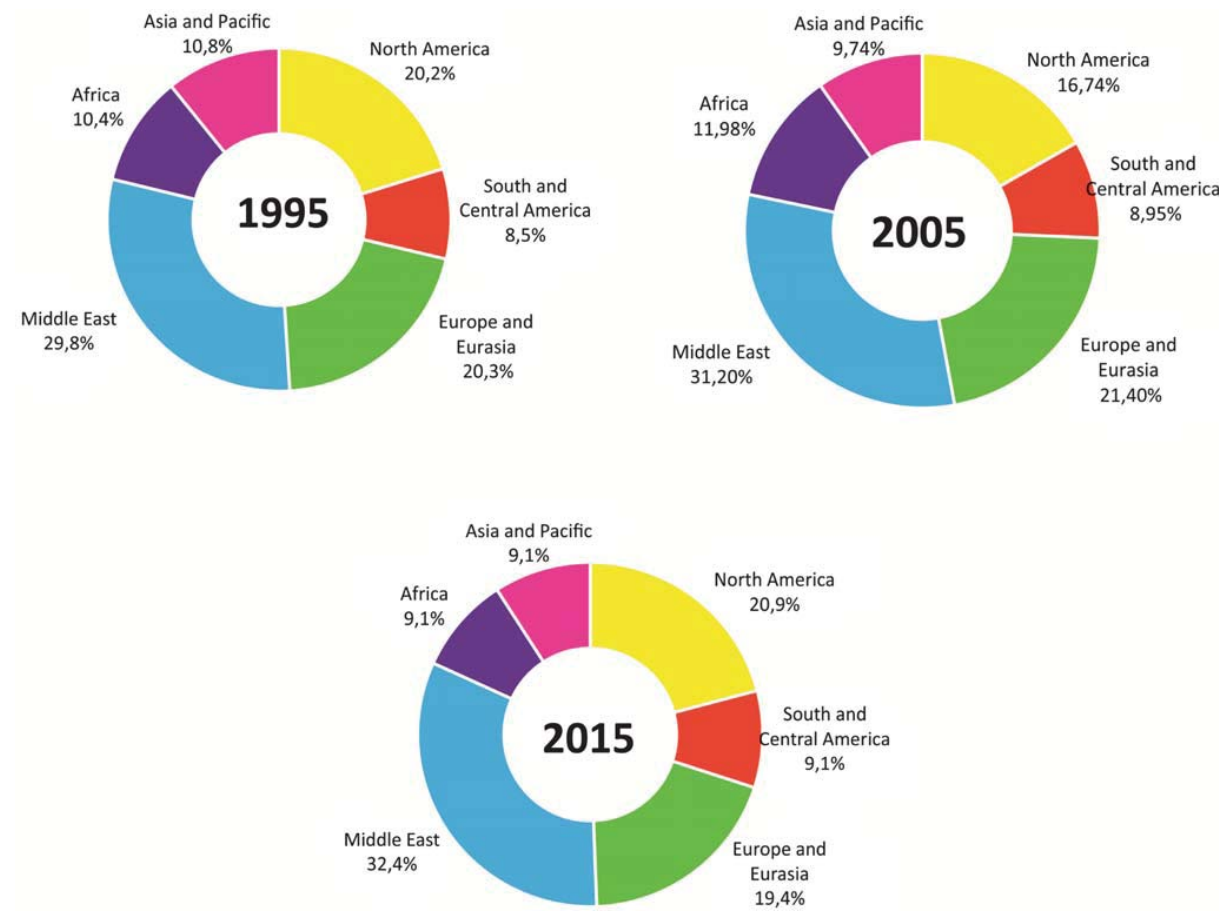

Figure 2: Distribution of Oil Production in the world 1995, 2005 and 2015 (adjusted to: BP, 2016)

feasible obtained at a given moment (Velić et al., 2015). According to BP data from 2015, in the Middle East there is $47.3 \%$ of oil reserves followed by South and Central America with $19.4 \%$ and North America has $14.0 \%$ reserves. Europe has less than $10 \%$ of oil reserves and Eurasia has $9.1 \%$. Of the total oil reserves, $7.6 \%$ is located in Africa and $2.5 \%$ in Asia and the
Pacific while the remaining countries have only $0.1 \%$ of the total amount of oil reserves in the world (see Figure 1).

Oil capture involves two different, but closely related general systems. These are the field, which represents a natural porous space with features for storing and flowing fluid and artificial creation, which includes a well, 
depth and surface equipment of the well, surface collecting system and equipment for separating and storing fluid. The field supplies a well with oil which with its depth and surface equipment allows oil to flow from the bottom of the well to the surface and allows for oil flow control (Čikeš, 2015).

Oil capture is not proportional to the amount of proven reserves owned by an individual country. Figure 2 shows the distribution of oil production in the world during 1995, 2005 and 2015. Oil production in 1995 amounts to $10.8 \times 10^{9} \mathrm{~m}^{3}$, in 2005 oil production was 13 $\times 10^{9} \mathrm{~m}^{3}$, and in 2015 was $14.6 \times 10^{9} \mathrm{~m}^{3}$ (BP, 2016). The reason for the steady increase in oil production can be attributed to increased oil demand in the market because of the needs of the world economy. In the last twenty years, rapid development of the industry has been recorded as well as a rise in global traffic. Saudi Arabia and South and Central America have the most significant growth in production over the years, while Asia and the Pacific and Europe recorded the largest fall in oil production.

\subsection{North America}

North America has $14 \%$ of oil reserves, the United States owns $3.2 \%$ or $8.7 \times 10^{9} \mathrm{~m}^{3}$ of total oil reserves,
Canada $10.1 \%$ or $27.4 \times 10^{9} \mathrm{~m}^{3}$, and Mexico $0.6 \%$ or 1.7 $\times 10^{9} \mathrm{~m}^{3}$ (see Figure 3).

In global oil production in 2015, North America has been involved with $20.9 \%$, whereby the United States exploits the most significant quantities, $13 \%$ or $2.020 \times$ $10^{9} \mathrm{~m}^{3}$. Comparing oil reserves and oil production in the United States, it can be concluded that production is not sustainable for a longer period of time, but year after year the quantities of exploited oil compensate themselves by new reserves.

Compared to 1995 when the US oil production gained $1.323 \times 10^{9} \mathrm{~m}^{3}$, in 2005 , production has fallen slightly and it was $1.097 \times 10^{9} \mathrm{~m}^{3}$ (see Figure 4). Oil exploration in the remaining countries of this region, Canada and Mexico, is much smaller than in the United States, so in 2015 , Canada had gained $0.697 \times 10^{9} \mathrm{~m}^{3}$ or $4.9 \%$ of oil, and Mexico $0.411 \times 10^{9} \mathrm{~m}^{3}$ or $2.9 \%$.

One of the most significant oilfields in the United States is Prudhoe Bay, discovered in 1967 within the same basin (Yergin, 1990). The field is an anticline structure located on Barrow Arch, with faulting on the north side of the arch and a Lower Cretaceous unconformity on the east side (Sweet, 2008). The basin is located within the Sadlerochit, Shublik and Sag River formations (Van Poollen et al., 1974). The porosity is
Figure 3: Oil reserves expressed in $10^{9} \mathrm{~m}^{3}$ in North America for 1995,2005 and 2015 (adapted to: BP, 2016)

Figure 4: Oil production expressed in $10^{9} \mathrm{~m}^{3}$ in North America during 1995, 2005 and 2015 (adjusted to: BP, 2016)
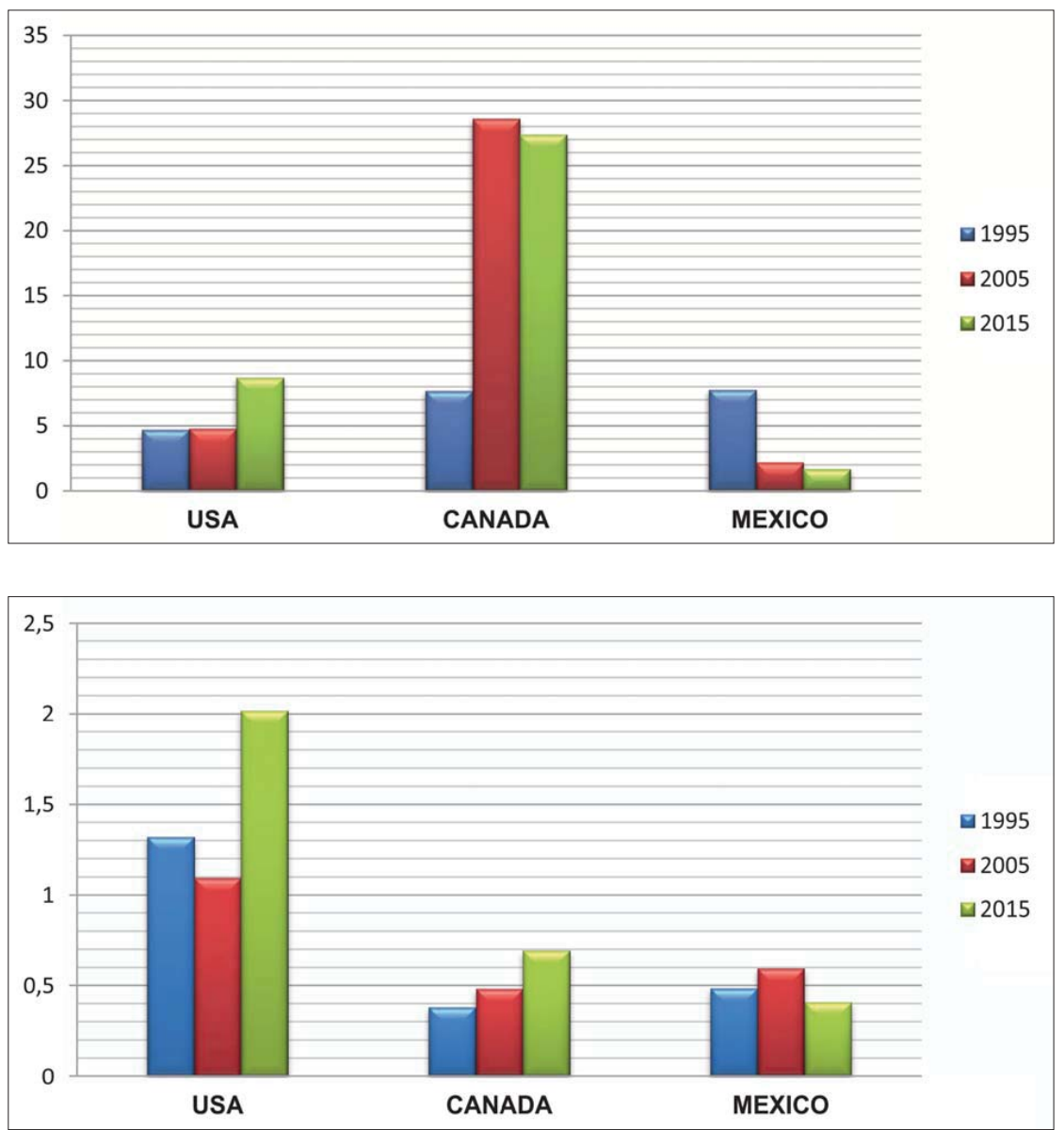

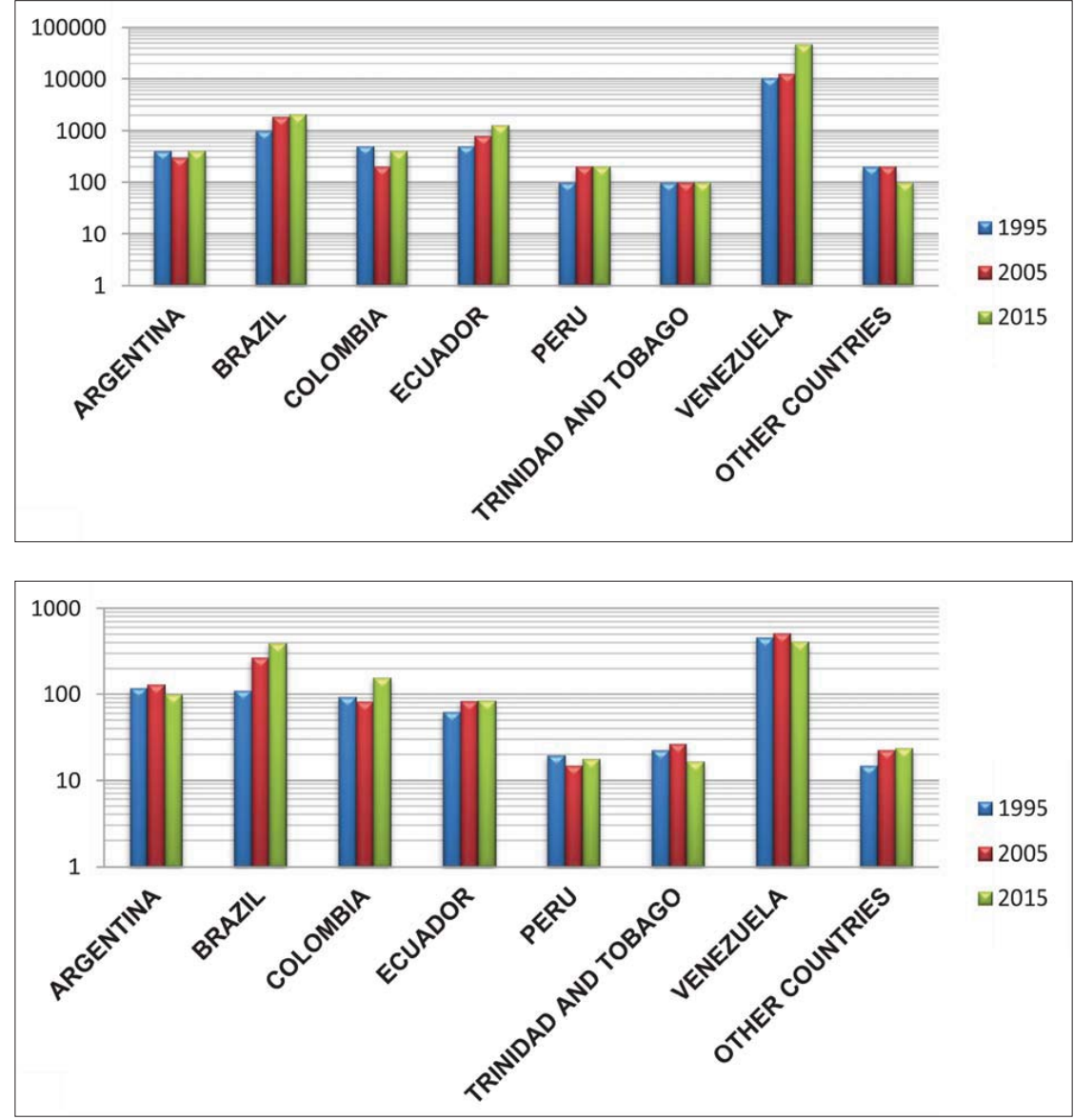

Figure 5: Oil reserves expressed in $10^{6} \mathrm{~m}^{3}$ in South and Middle America for 1995, 2005 and 2015 (adapted to: BP, 2016 about $25 \%$ and the permeability is around $0.270 \mu \mathrm{m}^{2}$ (Jamison et al., 1980).

The next important oilfield in the United States is East Texas located within the Cretaceous-age Woodbin Formation (Denne et al., 2016). The type of trap for hydrocarbons is stratigraphic. The source rock for the oil in East Texas is the overlying Eagle Ford Shale.

The Spraberry Trend, also known as the Spraberry Field is a large oilfield in the Permian Basin of West Texas. All oil is produced from a single enormous sedimentary unit known as the Spraberry Sand, which consists of complexly mixed fine sandstone and calcareous or silicate mudstone and siltstone, deposited in a deep water environment distinguished by channel systems and their associated submarine fans, all of Permian age. Oil has accumulated in stratigraphic traps (Wikipedia, 2018).

Canada is rich in hydrocarbons from an unconventional petroleum deposit, so-called oil sands. Estimated oil reserves in these deposits were determined in 2007 on the level of $1127.13 \times 10^{9} \mathrm{~m}^{3}$, and more than $95 \%$ of these reserves are located in the province of Alberta within the Sandstones from the Athabasca formation (Velić et al., 2015).

Two large oilfields are located in Mexico, Cantarell, which at the end of the last decade was the second larg- est field for exploitation, and Chicontepec, which is considered as an unconventional oilfield (Velić et al., 2015).

During the Cretaceous asteroid Chicxulub impactor hit the ground and it created the Chicxulub crater and subsequent carbonate-debris breccia, which became the oil reservoir (Barton et al., 2010). There are four blocks in the Cantarell Complex, Akal, Nohoch, Chac and Kutz (Acevedo, 1980).

\subsection{South and Middle America}

South and Central America own almost $20 \%$ of the world's oil reserves, of which only $17.7 \%$ or $47.8 \times 10^{9}$ $\mathrm{m}^{3}$ of oil is in Venezuela according to 2015 data, which holds the primacy in reserves. Venezuela, with the large amounts of proven reserves of oil in conventional reservoirs, has significant reserves in unconventional deposits. Brazil has $0.8 \%$ or $2.1 \times 10^{9} \mathrm{~m}^{3}$ of oil and Ecuador $0.5 \%$ or $1.3 \times 10^{9} \mathrm{~m}^{3}$. The remaining countries have less than $1 \%$ of the world's oil reserves. Those are Argentina and Colombia with $0.1 \%$ or $0.4 \times 10^{9} \mathrm{~m}^{3}$, Peru with 0.1 $\%$ or $0.2 \times 10^{9} \mathrm{~m}^{3}$, and with less than $0.1 \%$ in the total world reserves, Trinidad and Tobago, $0.1 \times 10^{9} \mathrm{~m}^{3}$ (see Figure 5).

According to BP data from 2015, in the world's total oil production South and Central America participate 
Figure 7: Oil reserves expressed in $10^{6} \mathrm{~m}^{3}$ in Europe and Eurasia for 1995, 2005 and 2015 (adapted to: BP, 2016)
Figure 8: Oil accumulation in Europe and Eurasia during 1995, 2005 and 2015. The production values are expressed in $10^{6} \mathrm{~m}^{3}$ (adjusted to: BP, 2016)
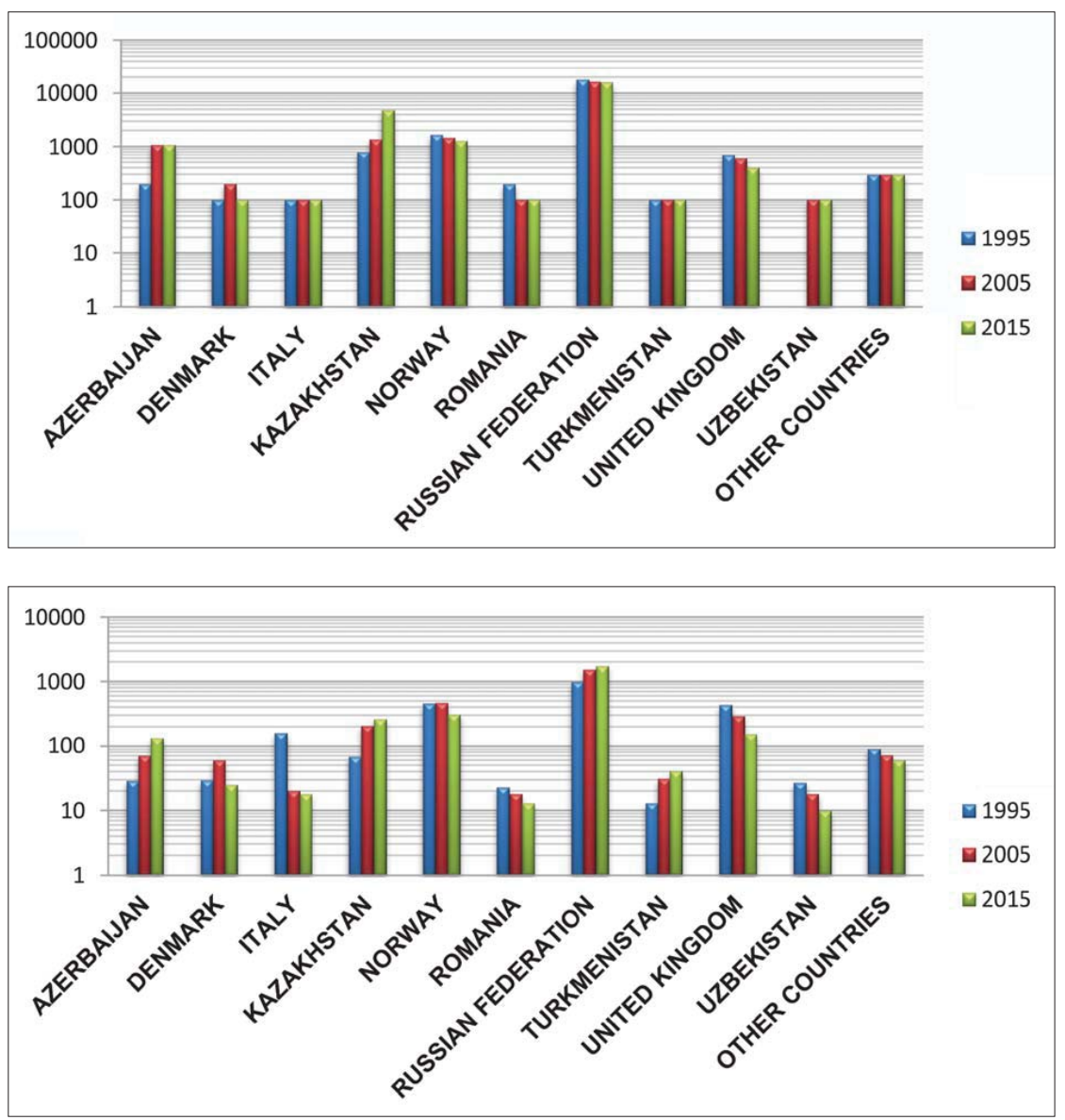

with $9.1 \%$ or $1.226 \times 10^{9} \mathrm{~m}^{3}$. Oil production in Venezuela was $3.1 \%$ or $0.417 \times 10^{9} \mathrm{~m}^{3}$ followed by Brazil, $3 \%$ or $0.402 \times 10^{9} \mathrm{~m}^{3}$ and Columbia, $1.2 \%$ or $0.160 \times 10^{9}$ $\mathrm{m}^{3}$. Argentina and Ecuador recorded a production of 0.7 $\%$ or $0.101 \times 10^{9} \mathrm{~m}^{3}, 0.086 \times 10^{9} \mathrm{~m}^{3}$ respectively. The lowest production was achieved in Peru and Trinidad and Tobago. It was about $0.017 \times 10^{9} \mathrm{~m}^{3}$ or $0.1 \%$ (see Figure 6).

In Venezuela, oil was discovered at the beginning of the $20^{\text {th }}$ century in jungles around the lake Maracaibo at a time when Venezuela was a rarely populated agricultural land with the key influence of the military in land management at all levels (Dekanić et al., 2004). In early 2011, President Hugo Chavez and the government announced that oil reserves in Venezuela are greater than in Saudi Arabia, and according to BP data, they are over $47.8 \times 10^{9} \mathrm{~m}^{3}$. The largest oilfield in Venezuela is Bolivar Coastal which was discovered in 1917. $94 \%$ of hydrocarbon reservoirs in the Maracaibo Basin are found within Eocene-Miocene clastic rocks (Talukdar and Marcano, 1994). The biggest production was achieved within the Trujillo and Musso formation, Eocene Age and La Rosa and Lagunillas, Miocene age. The accumulation of oil within the Miocene part of the reservoir happens in structural traps, while both, structural and strati- graphic traps are present within the Eocene (Borger and Lenert, 1959).

Another significant oil reservoir in Brazil is the field Lula or Tupi, which was discovered relatively recently, in 2006. The field was discovered in the geological formation known as Pre-salt.

\subsection{Europe and Eurasia}

The largest reserves of Europe and Eurasia in 2015 are in the Russian Federation, $6 \%$ or $16.3 \times 10^{9} \mathrm{~m}^{3}$. European oil reserves are located mostly in the North Sea, where Norway and the United Kingdom have the largest share. Norway owns $0.5 \%$ or $1,3 \times 10^{9} \mathrm{~m}^{3}$ of the world's oil reserves, while the United Kingdom has $0.2 \%$ or 0.4 $\times 10^{9} \mathrm{~m}^{3}$ of oil reserves. In Kazakhstan, there are $1.8 \%$ or $4.8 \times 10^{9} \mathrm{~m}^{3}$ of oil reserves, in Azerbaijan $0.4 \%$ or 1.1 $\times 10^{9} \mathrm{~m}^{3}$, while the remaining countries within Europe and Eurasia have much less reserves, about $0.1 \times 10^{9} \mathrm{~m}^{3}$ (see Figure 7).

In 2015 , the Russian Federation produced $12.4 \%$ or $1.746 \times 10^{9} \mathrm{~m}^{3}$ of oil, while total production in this region amounts $19.4 \%$ or $2,776 \times 10^{9} \mathrm{~m}^{3}$. Also, Norway has significant production in that year, $0.310 \times 10^{9} \mathrm{~m}^{3}$ or $2 \%$, Kazakhstan, $0.265 \times 10^{9} \mathrm{~m}^{3}$ or $1.8 \%$ and the United Kingdom, $0.153 \times 10^{9} \mathrm{~m}^{3}$ or $1 \%$. However, it should be 

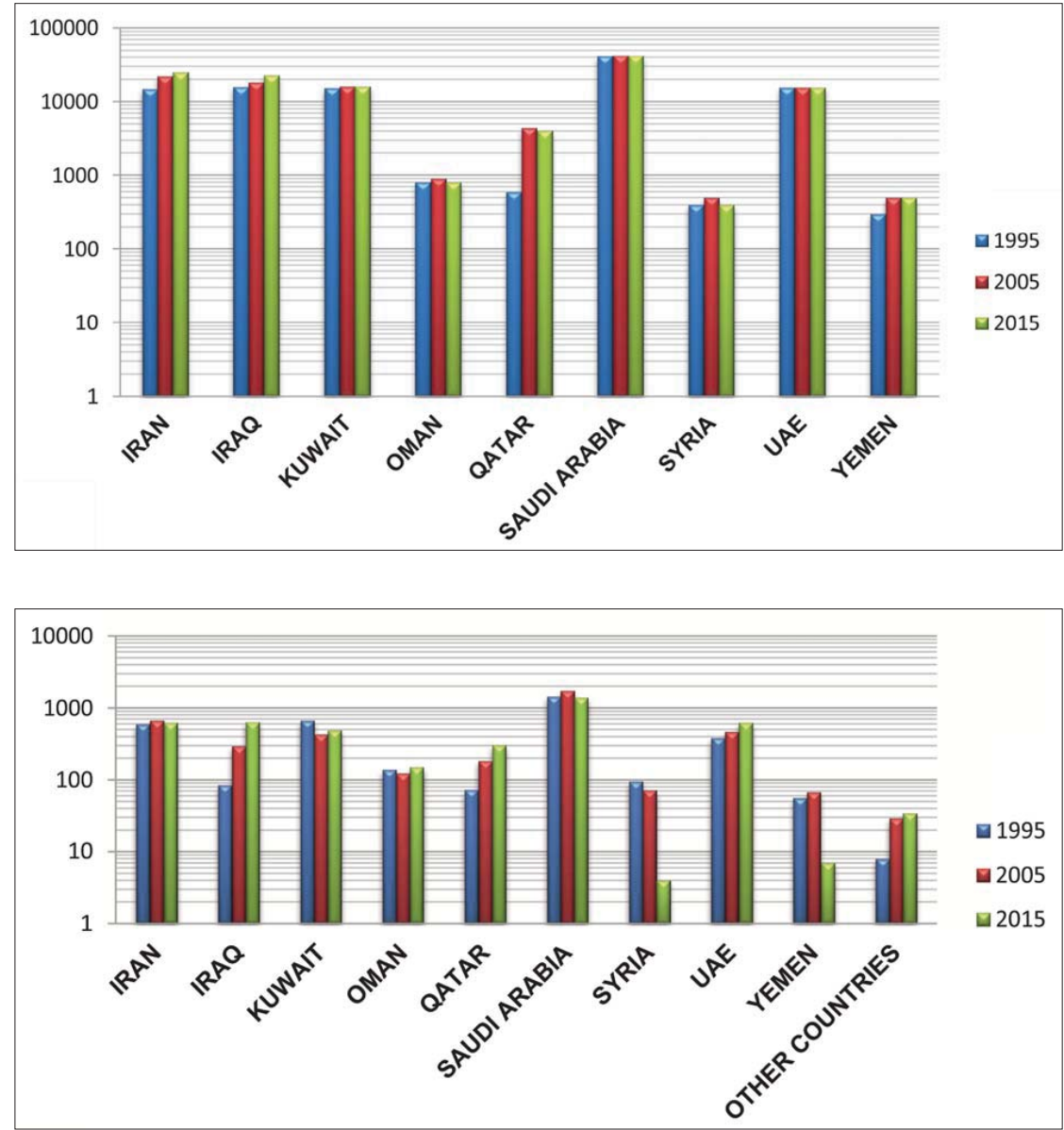

Figure 9: Oil reserves expressed in $10^{6} \mathrm{~m}^{3}$ at Middle East for 1995, 2005 and 2015 (adapted to: BP, 2016)
Figure 10: Oil production in the Middle East during 1995, 2005 and 2015. The gain values are expressed in $10^{6} \mathrm{~m}^{3}$ (adjusted to: $\mathrm{BP}, \mathbf{2 0 1 6}$ ) emphasized that the United Kingdom recorded a significant drop in production. During 1995 , it was $0.437 \times 10^{9}$ $\mathrm{m}^{3}$ and $20050.93 \times 10^{9} \mathrm{~m}^{3}$. During the reference years, Azerbaijan recorded a significant increase in production, so in 2015 , it was $1 \%$ or $0.134 \times 10^{9} \mathrm{~m}^{3}$ in the global oil exploitation. There is also Turkmenistan with $0.3 \%$ or $0.041 \times 10^{9} \mathrm{~m}^{3}$, Denmark with $0.025 \times 10^{9} \mathrm{~m}^{3}$ or $0.2 \%$, Italy with $0.018 \times 10^{9} \mathrm{~m}^{3}$ or $0.1 \%$, Romania with 0.013 $\times 10^{9} \mathrm{~m}^{3}$ or $0.1 \%$ and Uzbekistan $0.010 \times 10^{9} \mathrm{~m}^{3}$ or $0.1 \%$ (see Figure 8).

The Republic of Croatia has a rich history in oil and natural gas extraction and processing. Currently around $60 \%$ of the needs for gas and $20 \%$ of the needs for oil are covered by local extraction which is in decline, and in regards to expectations of increasing demand in the future, it will become necessary to import larger quantities (Velić et. al, 2016). Oil and natural gas have been produced onshore and natural gas also offshore in Croatia. $1.21 \times 10^{9} \mathrm{~m}^{3}$ of natural gas and $0.85 \times 10^{6} \mathrm{~m}^{3}$ of oil have been produced in Croatia in 2017. Despite all efforts for increasing hydrocarbon production, like the implementation of enhanced oil recovery (EOR) projects, production fell by $4.5 \%$ in comparison to 2016 (INA 2018). Croatia will certainly need new supply sources especially for natural gas if it wants to keep the high level of natural gas security of supply (Karasalihović et al. 2010, Sučić et al. 2011).

\subsection{The Middle East}

The largest proven oil reserves, according to data from 2015, are in the Middle East, $47.3 \%$. "The richest" has been Saudi Arabia with $15.7 \%$ or $42.4 \times 10^{9} \mathrm{~m}^{3}$ of oil. Others include Iran with $9.3 \%$ or oil reserves in the world $25.1 \times 10^{9} \mathrm{~m}^{3}$ and Iraq with $8.4 \%$ or $22.8 \times 10^{9} \mathrm{~m}^{3}$ oil reserves. Kuwait possesses $6 \%$ or $16.1 \times 10^{9} \mathrm{~m}^{3}$ of oil reserves, and the United Arab Emirates $5.8 \%$ or 15.5 $\times 10^{9} \mathrm{~m}^{3} .4 .1 \times 10^{9} \mathrm{~m}^{3}$ or $1.5 \%$ of the world reserves has belonged to Qatar, and other countries in the Middle East have had less than $1 \%$ of oil reserves. There has been Oman with $0.3 \%$ or $0.8 \times 10^{9} \mathrm{~m}^{3}$, Yemen with 0.2 $\%$ or $0.5 \times 10^{9} \mathrm{~m}^{3}$ and Syria with $0.1 \%$ or $0.4 \times 10^{9} \mathrm{~m}^{3}$ oil reserves (see Figure 9).

The Middle East, as the region with the largest reserves of oil, is also the region with the highest oil production with $33 \%$ or $4.785 \times 10^{9} \mathrm{~m}^{3}$ in total world production. Saudi Arabia was the largest producer of oil with $1.910 \times$ $10^{9} \mathrm{~m}^{3}$ produced oil in 2015. Compared to Saudi Arabia, the remaining countries of the Middle East have far less production. During 1995, Iraq produced $0.084 \times 10^{9} \mathrm{~m}^{3}$, during 2005 it was $0.291 \times 10^{9} \mathrm{~m}^{3}$, and $0.641 \times 10^{9} \mathrm{~m}^{3}$ or 
Figure 11: Oil reserves expressed in $10^{6} \mathrm{~m}^{3}$ in Africa for 1995, 2005 and 2015 (adapted to: BP, 2016)
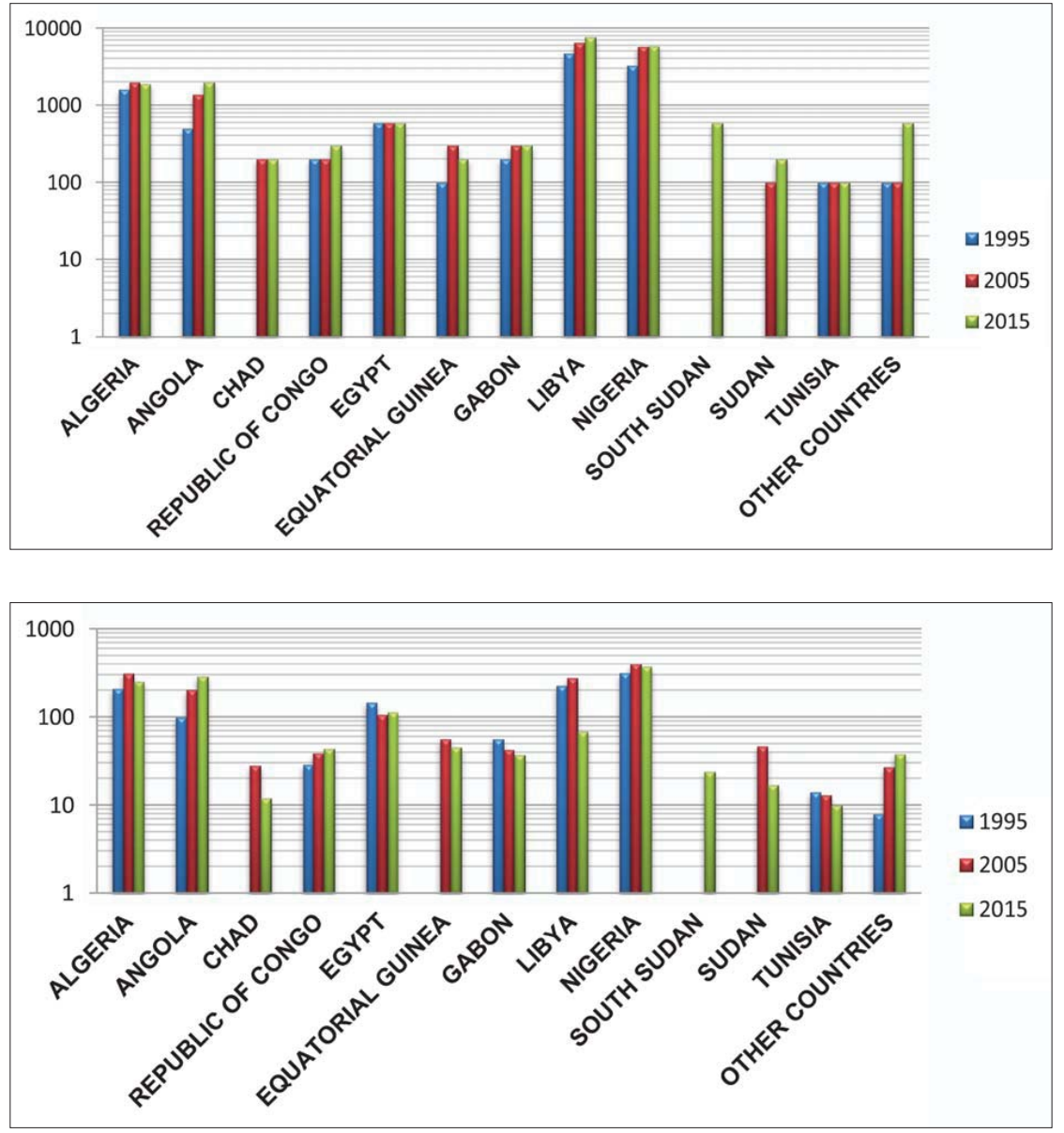

$4.5 \%$ in 2015 , which has made Iraq the country with the highest growth in the world. Following was Iran with production of $0.623 \times 10^{9} \mathrm{~m}^{3}$ or $4.2 \%$ in 2015 and the United Arab Emirates with $0.620 \times 10^{9} \mathrm{~m}^{3}$ or $4 \% .0 .491 \times 10^{9} \mathrm{~m}^{3}$ of oil was produced in Kuwait, which was $3.4 \%$ worldwide, and $0.302 \times 10^{9} \mathrm{~m}^{3}$ or $1.8 \%$ in Qatar, which has also recorded an increase in production since 1995 up to now. Also, significant production was achieved in Oman, $1.1 \%$ or $0.151 \times 10^{9} \mathrm{~m}^{3}$, while Yemen and Syria gained less than $0.05 \%$ in 2015 (see Figure 10).

Ghawar oilfield (located in the province Al-Ahsi was discovered in 1948. With $280 \mathrm{~km}$ length and $30 \mathrm{~km}$ width, it is the largest oilfield in the world and it produces more than half of total oil production in Saudi Arabia. Approximately $60-65 \%$ of total Saudi oil production between 1948 and 2000 came from Ghawar. There is no more technical information available for this field. Available information is predominantly historical (pre-nationalization), from incidental technical publications, or anecdotal. Reservoir rocks are Jurassic Arab-D limestones with exceptional porosity (Velić et al., 2015).

\subsection{Africa}

Africa possesses $7.6 \%$ of the world's total oil reserves. Libya has the most significant reserves, $2.8 \%$ or
$7.7 \times 10^{9} \mathrm{~m}^{3}$, next is Nigeria with $2.2 \%$ or $5.9 \times 10^{9} \mathrm{~m}^{3}$ and Algeria and Angola with reserves of $0.7 \%$ or approximately $2.0 \times 10^{9} \mathrm{~m}^{3}$, while Egypt and South Sudan possess $0.2 \%$ or $0.6 \times 10^{9} \mathrm{~m}^{3}$. The Republic of Congo and Gabon have $0.1 \%$ or $0.3 \times 10^{9} \mathrm{~m}^{3}$ of oil reserves, and Chad, Equatorial Guinea and Sudan $0.1 \%$ or $0.2 \times$ $10^{9} \mathrm{~m}^{3}$, while the lowest oil reserves own Tunisia, $0.1 \times$ $10^{9} \mathrm{~m}^{3}$ or less than $0.1 \%$ in the world's oil reserves (see Figure 11).

The biggest production for most of the countries of this region was achieved in 2005 and it was $1.560 \times 10^{9}$ $\mathrm{m}^{3}$, while in 2015 , it was $1.332 \times 10^{9} \mathrm{~m}^{3}$ and the lowest production was in $1995,1.131 \times 10^{9} \mathrm{~m}^{3}$. Nigeria has the highest production in this region, $0.374 \times 10^{9} \mathrm{~m}^{3}$, or 2.6 $\%$ in the total world production. In the world's total oil production, Angola is involved with $2 \%$ or $0.289 \times 10^{9}$ $\mathrm{m}^{3}$, and Algeria with $1.6 \%$ or $0.252 \times 10^{9} \mathrm{~m}^{3}$. Libya is the country with the greatest oil reserves in Africa and during 1995 and 2005, it achieved a significant production of $0.229 \times 10^{9} \mathrm{~m}^{3}$ or $0.277 \times 10^{9} \mathrm{~m}^{3}$. However, due to the difficult economic situation and the war in 2011, during 2015 there was a recorded decrease in exploitation of about $75 \%$ and it was only $0.069 \times 10^{9} \mathrm{~m}^{3}$. Significant production was made in Egypt, $0.115 \times 10^{9} \mathrm{~m}^{3}$ or $0.8 \%$, Equatorial Guinea, the Republic of Congo and 

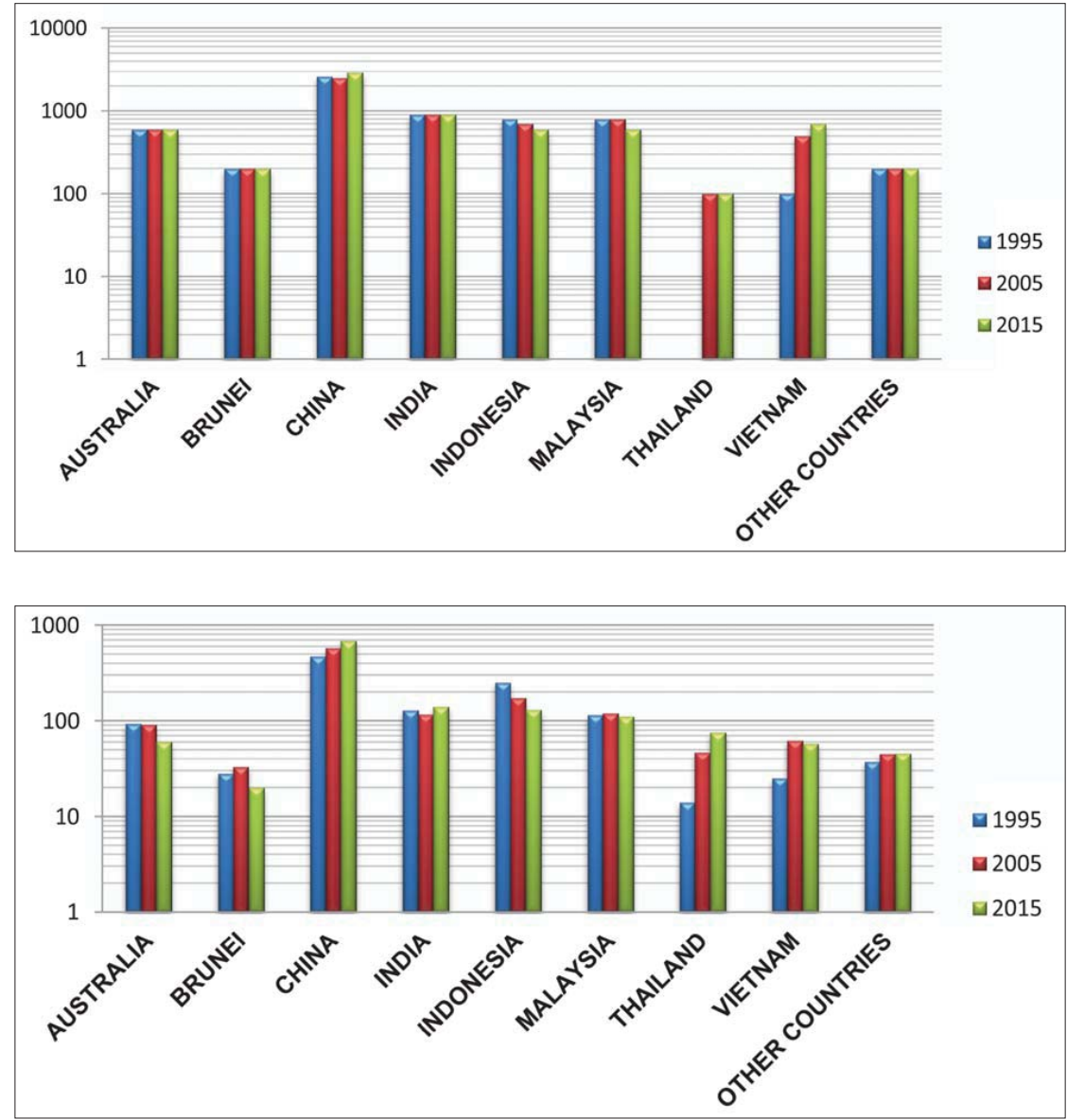

Figure 13: Oil reserves expressed in $10^{6} \mathrm{~m}^{3}$ in Asia and Pacific for 1995, 2005 and 2015 (adapted to: BP, 2016)
Figure 14: Oil production in Asia and the Pacific during 1995, 2005 and 2015. The gain values are expressed in $10^{6} \mathrm{~m}^{3}$ (adjusted to: BP, 2016)
Gabon participate in the overall oil production with 0.3 $\%$ or $0.046 \times 10^{9} \mathrm{~m}^{3}$, Equatorial Guinea with $0.044 \times 10^{9}$ $\mathrm{m}^{3}$, and the Republic of Congo and Gabon with $0.037 \times$ $10^{9} \mathrm{~m}^{3}$. According to the BP report from 2016, there is no data for South Sudan production during 1995 and 2005, while in 2015 , it amounted to $0.024 \times 10^{9} \mathrm{~m}^{3}$ or $0.2 \%$. Following was Sudan with production of $0.017 \times 10^{9} \mathrm{~m}^{3}$ or $0.1 \%$ in 2015 , but that was a decline of $64 \%$ compared to 2005 when it produced $0.047 \times 10^{9} \mathrm{~m}^{3}$. The countries with the lowest production in this region are Chad with $0.012 \times 10^{9} \mathrm{~m}^{3}$ of oil and Tunisia with 0.010 $\times 10^{9} \mathrm{~m}^{3}$ of oil, each participating in the global oil production with $0.1 \%$ (see Figure 12).

The Sarir field was discovered in southern Cyrenaica during 1961 and is considered to be the largest oil field in Libya.

\subsection{Asia and Pacific}

Asia and the Pacific have the lowest oil reserves, only $2.5 \%$. In 2015, China had reserves of $1.1 \%$ or $2.9 \times 10^{9}$ $\mathrm{m}^{3}$, with significant reserves, but less than $0.3 \%$ were India, $0.9 \times 10^{9} \mathrm{~m}^{3}$, Vietnam, $0.7 \times 10^{9} \mathrm{~m}^{3}$ and Australia and Malaysia with $0,6 \times 10^{9} \mathrm{~m}^{3}$. Brunei owned only 0.2 $\times 10^{9} \mathrm{~m}^{3}$, while Thailand had $0.1 \times 10^{9} \mathrm{~m}^{3}$ of oil reserves (see Figure 13).
Asia and the Pacific in total world production during 2015 participate with $9.1 \%$. China produced $4.9 \%$ or $0.685 \times 10^{9} \mathrm{~m}^{3}$. Next were India and Indonesia with a production of $0.9 \%$ in 2015 , or $0.139 \times 10^{9} \mathrm{~m}^{3}$ for India and $0.131 \times 10^{9} \mathrm{~m}^{3}$ for Indonesia. In comparison with 1995, when Indonesia produced $0.251 \times 10^{9} \mathrm{~m}^{3}$, and 2005 and oil production of $0.117 \times 10^{9} \mathrm{~m}^{3}$, Indonesia recorded a significant decline. Malaysia produced 0.110 $\times 10^{9} \mathrm{~m}^{3}$ or $0.7 \%$ oil in 2015 , Thailand $0.076 \times 10^{9} \mathrm{~m}^{3}$, Australia $0.061 \times 10^{9} \mathrm{~m}^{3}$ and Vietnam $0.058 \times 10^{9} \mathrm{~m}^{3}$ or $0.4 \%$. The lowest production in $2015,0.1 \%$ or $0.020 \times$ $10^{9} \mathrm{~m}^{3}$ was in Brunei (see Figure 14).

\section{Reserves to Production $(\mathrm{R} / \mathrm{P})$ Ratio}

The $\mathrm{R} / \mathrm{P}$ ratio is the number of years during which an individual country or region with today's exploitation would exhaust the present reserves, assuming that neither the total amount of reserves nor the production of oil are changed. Figure $\mathbf{1 5}$ shows the R/P ratio in 2015 in the world. Since both parameters are very variable in practice, the $\mathrm{R} / \mathrm{P}$ ratio is intended exclusively for an estimation of global oil supply (Dekanić and Karasalihović Sedlar, 2016). 


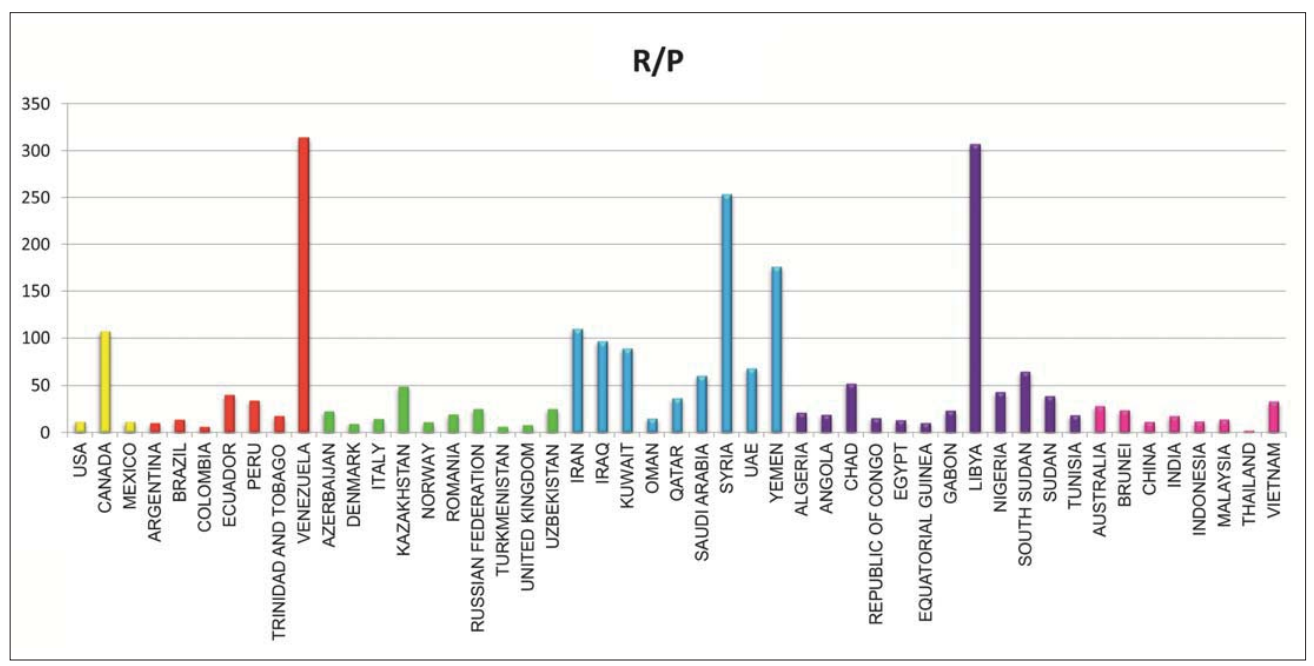

Figure 15: The R/P ratio in the world in 2015 (adapted to: BP, 2016)

\section{The Oil Prices}

Energy raw materials are economic goods with their value and price, which depends on their distribution and quantity. The oil market is represented with supply or exploitation of oil on one side and refinery processing or petroleum products consumption on the other (Nosić et al., 2017). When it comes to oil prices in the market, it is thought of the value of oil expressed in USD per barrel at a certain point on a particular market (Dekanić et al., 2004). The minimum oil price is always determined by maximum production costs, increased for profit. The same law applies to the lower oil price limit. This limit will always determine the costs of exploiting the most expensive unit of produced oil. Unlike the minimum oil price, which is determined by the cost of oil production, the maximum price is determined by the consumer's readiness for oil derivatives (Grubišić, 2009). The value of oil reserves is an indicator for future profit of their production, as well as an indicator for judgment for the future management of energy companies because the value of the reserves enters into the value of the company's core capital. The production cost of a single oil barrel is the most important component during the determination of profitability of exploitation and it ranges according to both, petroleum properties and drilling methods.

The main crude oil markets in the world are the North Sea, West Africa, the Mediterranean market, the Persian Gulf, the Asian region and the East and West coast of the United States. Depending on the market, there are several markers for crude oil price, such as Dated Brent, Dubai/Fateh, West Texas Intermediate (WTI), Alaska North Slope, (ANS) and Tapis \& Minas (Nosić et al., 2017). Figures 16, 17, 18 and 19 show oil price trends of the above mentioned oil types from 1980 to 2015.

In 1979, a gradual rise in oil prices had started, as a result of production and export quotas of OPEC mem-

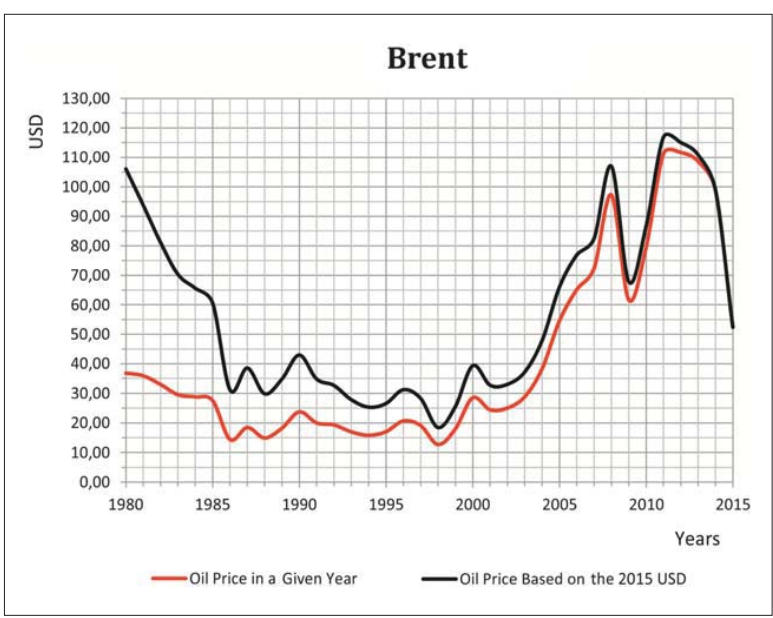

Figure 16: Brent oil price trends from 1980 to 2015 according to BP data (2016)

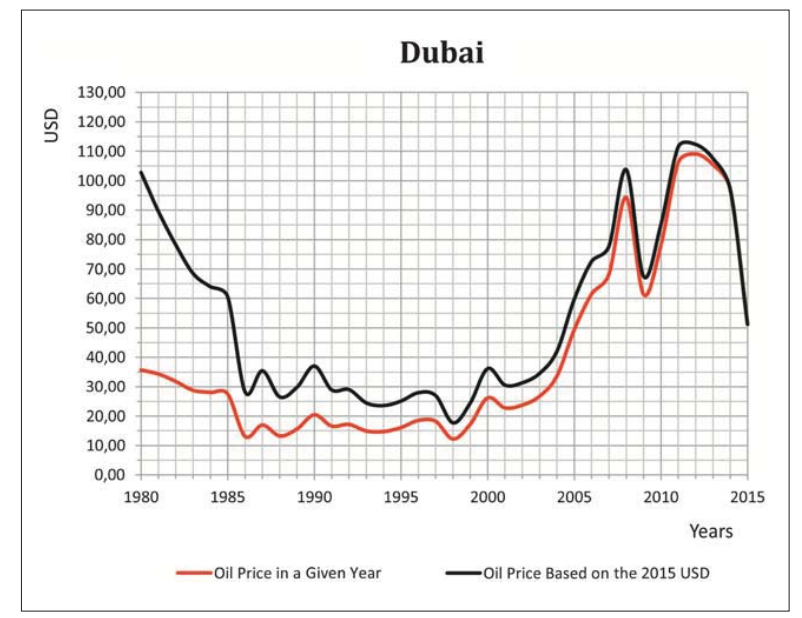

Figure 17: Dubai oil price trends from 1980 to 2015 according to BP data (2016) 


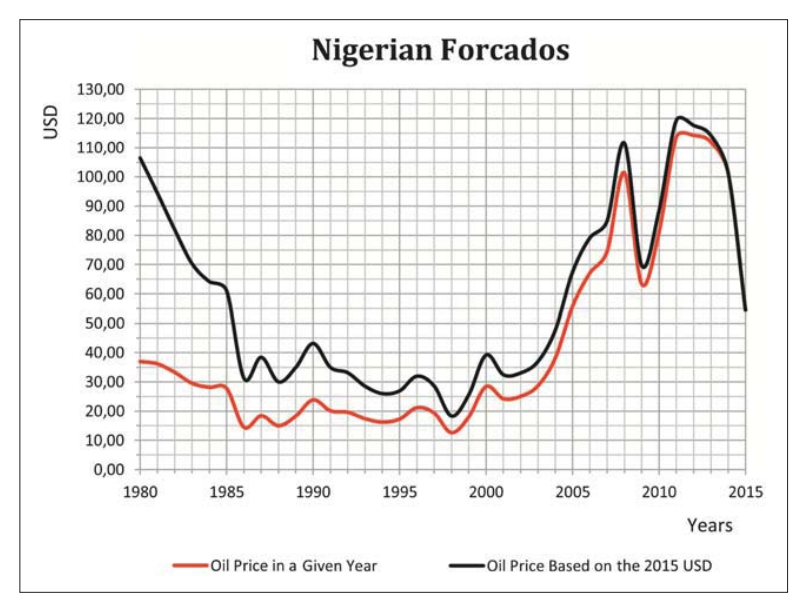

Figure 18: Nigerian Forcados oil price trends from 1980 to 2015 according to BP data (2016)

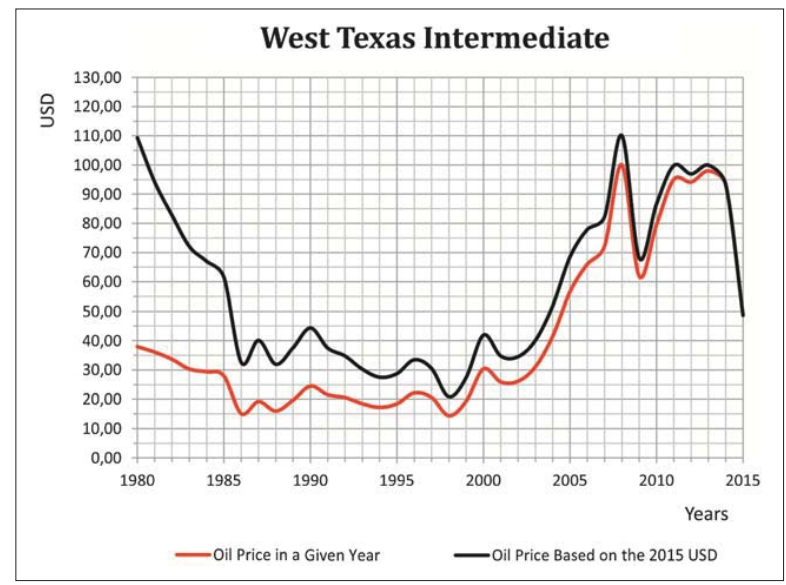

Figure 19: West Texas Intermediate oil price trends from 1980 to 2015 according to BP data (2016)

bers. In the 1980s, oil business began at the New York Stock Exchange. Oil has become a good for exchange and sold well in the market, but the prices have become unstable and unsafe. Customers have been able to buy oil at a certain price, and producers could sell oil, even before its production (Yergin, 1991). After the first crisis in 1973 and the other crisis in 1979, with an excessive supply of oil in 1986, the oil price fell below 30 USD per barrel. After that, oil prices rose steadily up to the end of the 1990s. The beginning of 2000s was characterized by a significant increase in oil prices. Thus, in 2008 the price of an oil barrel was over 100 USD. Energy consumption grew until 2007, and after the financial crisis in the United States and the economic recession (Dekanić, 2011). After the decline of oil prices at the beginning of 2009 to 70 USD for barrel, prices began to rise again, and at the end of 2009 and early 2010, the price was between 65 and 90 USD per barrel. During 2011 and 2012, the price of oil was above 100 USD, and fell to 50 USD in 2015. Various causes have influenced the constant change of oil prices, yet the most prominent have been the geopolitical and economic crises of oil producers, wars and the huge increase in demand for the most populous countries in the world (such as China, India and Brazil). Oil prices depend primarily on geopolitical conditions, R/P ratio and surpluses of unused refinery capacities and oil reserves (Cerić, 2012). Hence, $\mathrm{BP}$ predicts that countries of rapid economic development, China and India, will play the leading role in increasing energy consumption in the coming years. Predictions are that demand for energy will rise $37 \%$ until 2035 , i.e. the increase will be $1.4 \%$ per annum. According to BP's estimates, the oil market will grow by $0.8 \%$ per annum.

\section{Discussion and Conclusion}

The contemporary world and economy are unimaginable without a constant energy supply. Among the primary forms of energy, the most important are oil and gas, which have almost completely changed human lifestyle.

At the beginning of the 20th century, oil penetrated in energy consumption and became a part of everyday life, economy and politics. Today, it is clear that economic and political power coincides with the main pillars of energy geopolitics. Humanity, however, does not have long-term fixed and secure supplies of energy with regard to the current mode of its use (Topić, 2017).

Although BP's data shows a global increase in oil reserves, which were $179.1 \times 10^{9} \mathrm{~m}^{3}$ in $1995,218.5 \times 10^{9}$ $\mathrm{m}^{3}$ in 2005 , and $269.9 \times 10^{9} \mathrm{~m}^{3}$ in 2015 , continuing its current use for energy, the oil reserves might disappear within half a century. The reason for this are numerous unconventional oil fields such as those in Alberta, Canada, but those alternatives have not been technologically or commercially suitable for environmentally suitable use, yet. By analysing oil reserves, oil production and movements of oil prices, it can be concluded that almost every increase in oil production, after the discovery of oil deposits, was later accompanied by a decrease in prices. In other words, the discovery of oil would stimulate prosperity, and then the oil price crashes. That decline in oil prices will lead to a fall in production. In addition, political instability and tensions, as well as war threats, have an impact on raising the uncertainty of oil production.

Due to the growing demand and demand of energy, there will be an increase in exploitation capacity, which will result in new research in deeper parts of the Earth's surface, in the underwater or in polar regions. Most of the world's future productions are expected in developing countries, because they have the most profitable production capacities and facilities.

\section{References}

Acevedo, J.S., Giant Fields of the Southern Zone - Mexico, in Giant Oil and Gas Fields of the Decade: 1968-1978, 1980. 
AAPG Memoir 30 (Halbouty, M.T., ed.), American Association of Petroleum Geologists, Tulsa, 382 p.

Barton, R., Bird, K., Hernandez, J.G., Grajales-Nishimura, J.M., Murillo-Muneton, G., Herber, B., Weimer, P., Koeberl, C., Neumaier, M., Schenk, O., Stark, J. (2010): High Impact Reservoirs. Oilfield Review, Schlumberger, Houston, 14-29.

Borger, H.D., Lenert, D. B. (1959): The Geology and Development of the Bolivar Coastal Field at Maracaibo, Venezuela. $5^{\text {th }}$ World Petroleum Congress, Proceedings, sec. 1, p. 481-498.

Cerić, E. (2012): Nafta, procesi i proizvodi (Oil, Processes and Product). $2^{\text {nd }}$ edited edition, IBD d.o.o \& Dobra knjiga, Sarajevo 424 p. (in Croatian)

Čikeš, M. (2015): Proizvodno inženjerstvo nafte i plina $(P e$ troleum Production Engineering). University of Zagreb, Faculty of Mining, Geology and Petroleum Engineering, Zagreb, 525 p. (in Croatian)

Denne, R.A., Breyer, J.A., Callender, A.D., Hinote, R.E., Kariminia, M., Kosanke, T.H., Kita, Z., Lees, J.A., Rowe, H., Spaw, J.M., And Tur, N. (2016): Biostratigraphic and geochemical constraints on the stratigraphy and depositional environments of the Eagle Ford and Woodbine Groups of Texas (in Breyer, J.A., ed., The Eagle Ford Shale: A renaissance in U.S. oil production), AAPG Memoir, 110, 84 p.

Dekanić, I. (2011): Geopolitika energije: uloga energije u suvremenom globaliziranom gospodarstvu (Energy Geopolitics: the role of energy in a modernized globalized economy). Golden marketing-Tehnička knjiga, Zagreb, 384 p. (in Croatian)

Dekanić, I., Kolundžić, S., Karasalihović, D. (2004): Stoljeće nafte: veza između nafte, novca i moći koja je promijenila svijet (A Century of Oil: The Nexus of Oil, Money and Power That Has Changed the World). 2nd extended and changed edition, Naklada Zadro, Zagreb, 563 p. (in Croatian and English)

Dekanić, I., Karasalihović Sedlar, D. (2016): Ekonomika energije: Proizvodnja, potrošnja, korištenje i trgovanje energijom u suvremenu globaliziranom gospodarstvu (Energy Economics: Production, Consumption, Use and Energy Trading in a Modern Globalized Economy). Golden marketing-Tehnička knjiga, Zagreb, 495 p. (in Croatian)

Grubišić, N. (2009): Dugoročni izgledi cijena nafte i plina (Long-term prospects of oil and gas prices). Energija, 1, 14-25. (in Croatian)

Hubbert, M.K. (1969): Energy Resources. In: Resources and Man (ed. Cloud, P.E.), National Academy of Science - National Research Council, Committee on Resources and Man, W. H. Freeman, San Francisco, pp. 157-242.

Jamison, H.C., Brockett, L.D. and Mcintosh, R. A. (1980): Prudhoe Bay - a Ten-Year Perspective; American Association of Petroleum Geologists, Memoir No. 30, p. 289 - 314.

Karasalihović Sedlar, D., Hrnčević, L., Dekanić, I. (2010): Possibilities for Implementation of Energy Strategy of the Republic of Croatia. Strojarstvo, 52, 6, 621-629.

Nosić, A., Karasalihovć Sedlar, D., Jukić, L. (2017): Oil and Gas Futures and Options Market, Rudarsko-geološko- naftni zbornik (The Mining-Geology-Petroleum Engineering Bulletin), 38, 45-54.

Sučić, D., Karasalihović Sedlar, D., Hrnčević, L. (2011): Analiza značaja projekata dobave prirodnog plina za Europu Južni tok i Nabucco (Natural gas Supply Projects for Europe-South Stream and Nabucco). Rudarsko-geološkonaftni zbornik (The Mining-Geology-Petroleum Engineering Bulletin), 23, 15-24. (in Croatian with English abstract)

Sweet, J.M. (2008): Discovery at Prudhoe Bay Oil. Blaine: Hancock House, 183 p.

Talukdar, S.C., and Marcano, Fernando, 1994, Petroleum systems of the Maracaibo Basin, Venezuela, in Magoon, L.B., and Dow, W.G., eds., The petroleum system-From source to trap: American Association of Petroleum Geologists Memoir, 60, 463-481.

Topić, M. (2017): Rezerve, pridobivanje i kretanja cijena nafte u svijetu tijekom 1995., 2005. i 2015. godine (Oil Reserves, Production and Oil Price Trend in World During 1995, 2005 and 2015). Graduate thesis, University of Zagreb, Faculty of Mining, Geology and Petroleum Engineering, Zagreb, 39 p. (in Croatian with English abstract)

Van Poollen and Associates (1974): In Place Volumetric Determination of Reservoir Fluids, Sadlerochit Formation, Prudhoe Bay Field, AOGCC Conservation Order No. 145 File, Inc. and State of Alaska Division of Oil and Gas.

Velić, J., Malvić, T., Cvetković, M. (2015): Geologija i istraživanje ležišta ugljikovodika (Geology and exploration of hydrocarbon reservoirs). University of Zagreb, Faculty of Mining, Geology and Petroleum Engineering, Zagreb, 144 p.

Velić, J., Kišić, K., Krasić, D. (2016): The Characteristics of The Production and Processing Oof Oil and Natural Gas in Croatia from 2000 to 2014. Rudarsko-geološko-naftni zbornik (The Mining-Geology-Petroleum Engineering Bulletin), 31, 2, 69-112. DOI:10.17794/ rgn.2016.2.6

Yergin, D. (1991): The Prize. Simon \&Schuster, New York London, $726 \mathrm{p}$.

\section{Internet sources:}

BP (2015): Outlook in brief. http://www.bp.com/en/global/ corporate/energy-economics/energy-outlook-2035/outlook-in-brief.html (accessed 8th August 2016)

BP (2016): Statistical Review of World Energy. https://www. bp.com/en/global/corporate/energy-economics/statisticalreview-of-world-energy.html (accessed 9th July 2018)

https://en.wikipedia.org/wiki/Cantarell_Field, (accessed 18th May 2018)

https://en.wikipedia.org/wiki/Spraberry_Trend (accessed 21st May 2018)

INA Oil Industry (2018): Annual Financial Report 2017. https://www.ina.hr/UserDocsImages/dokumenti//INA_AR_ 2017_cro_30_4\%20FINAL_link.pdf (accessed 8th August 2016)

The Mining-Geology-Petroleum Engineering Bulletin and the authors $\odot$, 2018, pp. 105-116, DOI: 10.17794/rgn.2018.4.10 